\title{
GROWTH OF JUVENILE GREEN SNAIL (TURBO MARMORATUS) CULTURED IN CAGES PLACED AT DIFFERENT DEPTHS
}

\author{
S. A. P. Dwiono ${ }^{1}$ and D. E. D. Setyono ${ }^{2}$ \\ ${ }^{1}$ Mataram Marine Bio Industry Technical Implementation Unit, Teluk Kodek, Malaka, Pemenang, \\ Lombok Barat 83352, Nusa Tenggara Barat.e-mail: sigit_dwiono@yahoo.com \\ ${ }^{2}$ Research Center for Oceanography, Jl. Pasir Putih 1 Ancol Timur, Jakarta 14430.
}

\begin{abstract}
This research was part of successive studies on culture techniques of juvenile green snail (Turbo marmoratus). This study was carried out for 14 weeks in coastal waters of Morella, Ambon Island. Three cages were placed at depths of $0 \mathrm{~m}, 4 \mathrm{~m}$ and $8 \mathrm{~m}$ below mean sea level. Each cage had a bottom area of $0.81 \mathrm{~m}^{2}$ and was stocked with 20 green snail juveniles of $40-50 \mathrm{~mm}$ shell diameter. During the first 4 weeks, juveniles reared at $0 \mathrm{~m}$ deep showed lowest instantaneous growth, while those reared at $8 \mathrm{~m}$ deep attained highest instantaneous growth. The instantaneous growth decreased significantly over 6 weeks for juveniles reared at $4 \mathrm{~m}$ and $8 \mathrm{~m}$ deeps. Over 14 weeks, juveniles reared at $8 \mathrm{~m}$ deep had higher daily growth than those at $0 \mathrm{~m}$ deep. It is recommended that to grow green snail juveniles at $8 \mathrm{~m}$ deep without any food complement, the substrates (coral rubbles) in the cages need to be renewed every 4 weeks with ones covered with microalgae.
\end{abstract}

Keywords: Growth, Green snail, Turbo marmoratus, Depths

\section{INTRODUCTION}

Green snail (Turbo marmoratus L.) or "burgos", in commercial market, is one of large herbivorous gastropods. This snail can reach 25 $\mathrm{cm}$ in shell diameter and $2 \mathrm{~kg}$ in weight (Kubo 1991, Yamaguchi 1993). It lives in habitat that is favorable for other herbivorous gastropods such as top snail (Trochus niloticus and T. pyramis). Stony coastal or dead coral reef area with good circulation of clear seawater is good habitat for this snail, and they can be found down to a depth of $20 \mathrm{~m}$ (Yamaguchi 1993). This animal creeps actively in the darkness (nocturnal), grazes on micro and macro algae that grow on rock, stone and dead coral.

Spawning experiment to produce small size juveniles had been successfully carried out in the hatchery of Ambon Marine Laboratory, Indonesian Institute of Sciences (Dwiono et al. 1997). Further studies have been carried out in the Laboratory, including study on food and feeding habit of small size juveniles $(<8 \mathrm{~mm}$ shell diameter $)$ fed with micro algae (Setyono \& Dwiono 1998) and feeding rate of juveniles with shell diameter ranging from $20 \mathrm{~mm}$ to $60 \mathrm{~mm}$ on macroalgae (Setyono \&
Dwiono 2003). However, for larger sizes juveniles there were lack of information for the growing out under natural condition particularly the effects of depth on growth.

The purpose of the present study was to clarify the effect of depth on the growth, which will be used as a basis for developing green snail aquaculture.

\section{MATERIALS AND METHODS}

\section{Juveniles}

Juveniles used in this study were produced in the hatchery of Ambon Marine Laboratory (LIPI) at Poka, Ambon (Dwiono et al. 1997). When the experiment started, the snails were about one year old with shell diameter ranged from 40 to $50 \mathrm{~mm}$.

\section{Cage Construction}

Cages were constructed by joining two prefabricated plastic trays supplied by Tooltech Pty. Ltd., forming a compartment of $90 \mathrm{~cm}$ long by 90 $\mathrm{cm}$ wide and $20 \mathrm{~cm}$ high. The trays had a rigid plastic mesh of $12 \mathrm{~mm}$. Each cage had a bottom 
area of $0.81 \mathrm{~m}^{2}$. Cages were lined with fine netting ( $2 \mathrm{~mm}$ mesh size) to ensure that most small benthic predators (e.g. whelks, Morula spp) were excluded. They were then filled with coral rubbles, fastened on a concrete block, and placed on intertidal area of Morella, Ambon Island (Fig. 1).

In order to eliminate possible chemical contamination from plastic trays and cement mixtures, and to allow micro algae as food for the snail to grow naturally in the cages, the cages were submerged in water and left undisturbed for two weeks before the experiment was started.

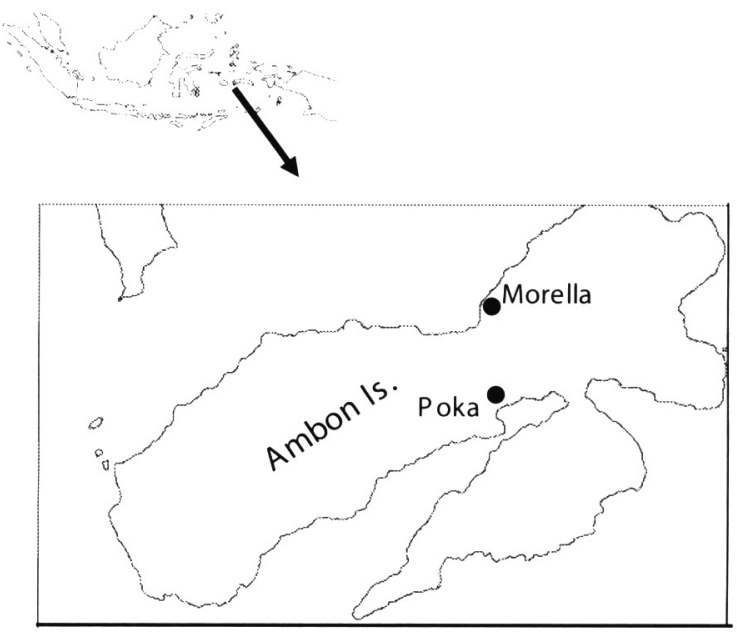

Figure 1. The locations of hatchery at Poka, and field experiment at Morella, in Ambon Island.

\section{Treatment and Measurement}

Three depth levels were chosen, i.e., $0 \mathrm{~m}, 4$ $\mathrm{m}$, and $8 \mathrm{~m}$ below mean sea level (MSL). Three cages were set at each depth and each cage was stocked with 20 juveniles of $40-50 \mathrm{~mm}$ shell diameter. Maximum shell diameter was measured with Mitutoyo digital caliper to the nearest 0.01 $\mathrm{mm}$ at the beginning of the experiment. The shell measurements were repeated every two weeks. Dead individuals were removed and replaced by snails of similar sizes. This study was carried out for 14 weeks.

\section{Data Analysis}

Instantaneous growth (IG), daily increase (DI) and relative growth $(\mathrm{RG})$ in shell diameter were calculated as follows:
IG $(m m$ per fortnight $)=\left(\right.$ shell diameter at $\left.t_{n}\right)-$ (shell diameter at $t_{n-1}$ )

DI $(\mathrm{mm}$ per day $)=$ increase in shell diameter $(\mathrm{mm}) /$ number of rearing days

RG $(\%)=[($ final shell diameter - initial shell diameter) / initial shell diameter] $\mathrm{x}$ $100 \%$

where: $\mathrm{t}$ is rearing time and $\mathrm{n}$ is number in fortnight

A nested analysis of variance (ANOVA) was used to test the significant levels of mean shell diameter, daily growth and relative growth between juveniles reared at different depths. The Least Significant Difference (LSD) test was used to identify significant differences between the mean values of different depth levels. Data were tested for a normal distribution and a square root transformation was done before the data were analyzed using ANOVA. The statistical analysis was performed using the software package DataDesk 4.1 (Data Description, Inc. Ithaca, N.Y.). The statistical significance level (P) was set at 0.05 .

\section{RESULTS}

Mean shell diameter at the time of measurement, daily growth, relative growth and total mortality are presented in Table 1. Data from $4 \mathrm{~m}$ depth were only available within 8 weeks of rearing because the cages were broken due to unknown incident and innumerable loss of individuals. Changes in mean shell diameter of the juvenile are shown in Figure 2. The mean initial shell diameters were not significantly different ( $P$ $>0.05$ ) between depth trials, except between those reared in depth of $4 \mathrm{~m}$ and $8 \mathrm{~m}(\mathrm{P}=0.02)$.

After 8 weeks of rearing, significantly highest $(\mathrm{P}<0.05)$ daily growth $(0.047 \pm 0.002 \mathrm{~mm})$ and relative growth $(6.21 \pm 0.24 \%)$ were found in juveniles reared at $8 \mathrm{~m}$, and it remained higher $(\mathrm{P}$ $=0.0303$ and $\mathrm{P}=0.0301$, respectively) over 14 weeks of rearing time than juveniles reared at $0 \mathrm{~m}$ (Table 1).

Figure 3 shows changes in instantaneous growth in shell diameter of juvenile green snail. At the first 4 weeks of rearing, juveniles reared at 8 $m$ deep resulted in the highest instantaneous growth, and then decreased significantly thereafter. Peak of instantaneous growth occurred at 6 th weeks of rearing time for juveniles reared 
Table 1. Mean and standard error of shell diameter, daily growth, relative growth and mortality of juvenile Turbo marmoratus reared at different depths in coastal waters of Morella, Ambon Island. Values at the same row sharing the same letter are not significantly different $(\mathrm{P}>0.05)$.

\begin{tabular}{|c|c|c|c|}
\hline \multirow{2}{*}{ Variable } & & Depth & \\
\hline & $\mathbf{0 ~ m}$ & $4 \mathrm{~m}$ & $8 \mathrm{~m}$ \\
\hline Mean shell diameter $(\mathrm{mm})$ at initial rearing time & $43.62 \pm 0.34^{\mathrm{a}, \mathrm{b}}$ & $44.08 \pm 0.31^{\mathrm{a}}$ & $42.81 \pm 0.27^{b}$ \\
\hline $\begin{array}{l}\text { Mean shell diameter }(\mathrm{mm}) \text { over } 8 \text { weeks of } \\
\text { rearing }\end{array}$ & $44.75 \pm 0.39^{\mathrm{a}}$ & $46.06 \pm 0.32^{b}$ & $45.45 \pm 0.25^{\mathrm{b}}$ \\
\hline $\begin{array}{l}\text { Mean shell diameter }(\mathrm{mm}) \text { over } 14 \text { weeks of } \\
\text { rearing }\end{array}$ & $45.30 \pm 0.39^{\mathrm{a}}$ & - & $45.48 \pm 0.27^{\mathrm{a}}$ \\
\hline $\begin{array}{l}\text { Daily increase in shell diameter }(\mathrm{mm}) \text { over } 8 \\
\text { weeks of rearing }\end{array}$ & $0.020 \pm 0.002^{\mathrm{a}}$ & $0.035 \pm 0.002^{\mathrm{b}}$ & $0.047 \pm 0.002^{\mathrm{c}}$ \\
\hline $\begin{array}{l}\text { Daily increase in shell diameter }(\mathrm{mm}) \text { over } 14 \\
\text { weeks of rearing }\end{array}$ & $0.016 \pm 0.001^{\mathrm{a}}$ & - & $0.027 \pm 0.001^{\mathrm{b}}$ \\
\hline $\begin{array}{l}\text { Relative increase in shell diameter }(\%) \text { over } 8 \\
\text { weeks of rearing }\end{array}$ & $2.57 \pm 0.27^{\mathrm{a}}$ & $4.50 \pm 0.21^{\mathrm{b}}$ & $6.21 \pm 0.24^{\mathrm{c}}$ \\
\hline $\begin{array}{l}\text { Relative increase in shell diameter (\%) over } 14 \\
\text { weeks of rearing }\end{array}$ & $3.65 \pm 0.30^{\mathrm{a}}$ & - & $6.28 \pm 0.26^{b}$ \\
\hline $\begin{array}{l}\text { Total mortality of } 60 \text { individuals over } 8 \text { weeks } \\
\text { of rearing }\end{array}$ & $2(3.3 \%)$ & $10(16.7 \%)$ & $3(5.0 \%)$ \\
\hline $\begin{array}{l}\text { Total mortality of } 60 \text { individuals over } 14 \text { weeks } \\
\text { of rearing }\end{array}$ & $7(11.7 \%)$ & - & $5(8.3 \%)$ \\
\hline
\end{tabular}

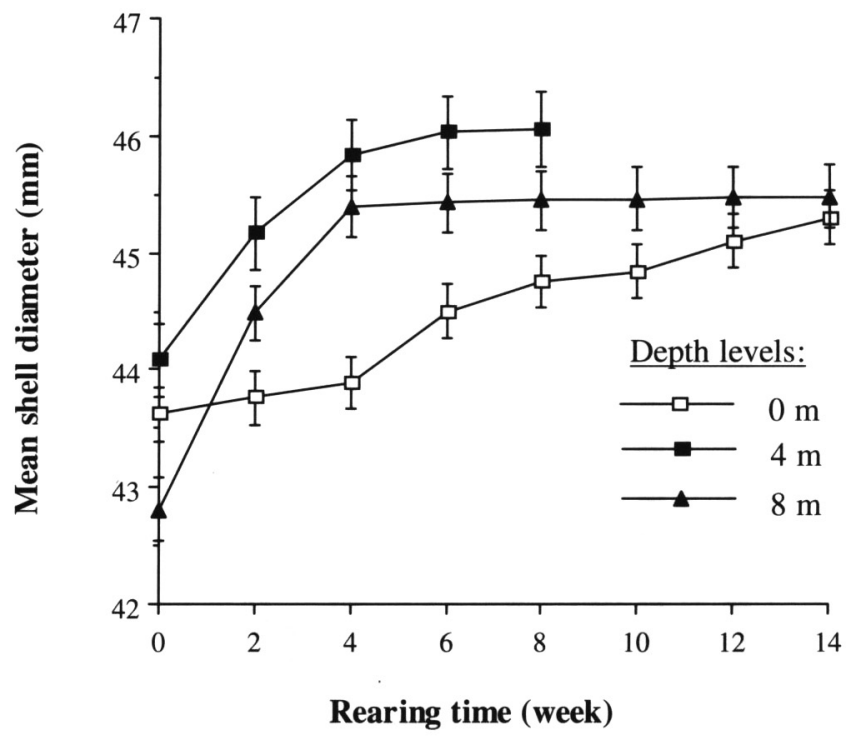

Figure 2. Changes in mean shell diameter for juvenile Turbo marmoratus reared at different depths. Values are mean and standard error.

at $0 \mathrm{~m}$ deep and remained stable thereafter. In general, instantaneous growth was low after 8 weeks of rearing in all depth trials, i.e., $<0.5 \mathrm{~mm}$ per fortnight.

When the cumulative growth is plotted against the time of observation (Figure 3), it reveals that the highest growth $(2.68 \pm 0.11 \mathrm{~mm})$ was shown by juveniles reared at $8 \mathrm{~m}$ deep, followed by those of $4 \mathrm{~m}$ deep, and lastly by the $0 \mathrm{~m}$ deep.
Mortality was relatively low (data not shown) at fortnight observation. It was about 2 and 3 individuals per fortnight (in total of all replicates) for all depth trials. At a longer period, juveniles reared at $8 \mathrm{~m}$ deep had lowest mortality (Table 1 ). The data do not indicate any relation between mortality and depth. 


\section{DISCUSSION}

Maximizing the growth rate is an important aspect for successful commercial aquaculture. A variety of factors such as suitable habitat (Setyono and Dwiono 1998), water quality, quantity and quality of food (Setyono and Dwiono 2003), and density (Dwiono and Setyono 1999; 2003) are known to influence the growth.

Within the first few (4-6) weeks of rearing, juveniles reared in all depths have relatively high $(>0.5 \mathrm{~mm})$ instantaneous growth (Figure 3$)$. The effect of feeding rate on instantaneous growth became increasingly significant after 4 and 6 weeks of rearing. This condition indicated that the quantity of food in the cage was no longer sufficient to promote the growth of the snails. Therefore, it is recommended to transfer the snails to a new prepared cages or replaced the coral rubbles in the cages (with growing micro algae as food) every 4 weeks, especially for juveniles reared at $8 \mathrm{~m}$ deep. Addition of new coral rubble covered with micro algae can supply food for the snails. Dwiono and Setyono (1999) found that the addition of coral rubble in the cage could increase the instantaneous growth during the first 8 weeks.

The effect of depth on the growth of juvenile green snail in this study is still unclear (Figure 4). However, it could be explained that depth (water pressure) may affect the formation of shell as the snail can still be found in a depth of $20 \mathrm{~m}$ (Yamaguchi 1993). The younger snail (small sizes) were mostly found in a shallow coastal waters, and the older one (bigger sizes) were found in a deeper waters (Personal Observation).

Turbo marmoratus is a sturdy snail. Setyono and Dwiono (1998) found that mortality of small juveniles (7-8 $\mathrm{mm}$ in shell diameter) was relatively low $(0-6 \%)$ within 12 weeks of rearing, and mortality for a larger sizes was not correlated with density (Dwiono and Setyono 1999; 2003). The present study shows that mortality was also not correlated with depth where the cages were placed.

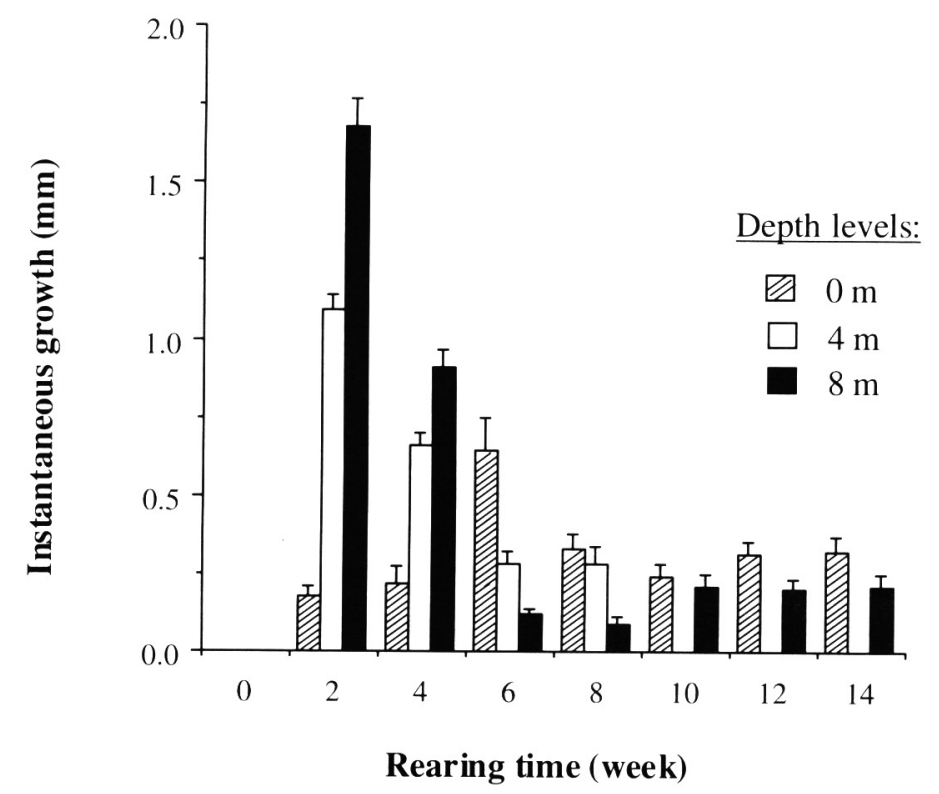

Figure 3. Changes in instantaneous growth for juvenile Turbo marmoratus reared at different depths. Values are mean and standard error. 


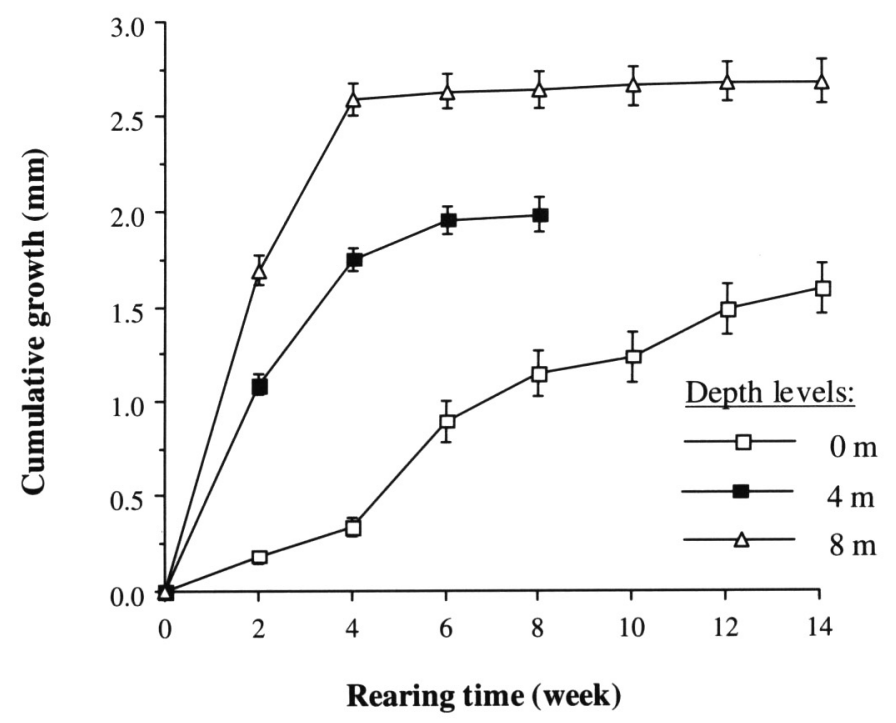

Figure 4. Changes in cumulative growth for juvenile Turbo marmoratus reared at different depths and. Values are mean and standard error.

\section{REFERENCES}

Dwiono, S.A.P., P.C. Makatipu \& Pradina 1997. A hatchery for topshell (Trochus niloticus) in eastern Indonesia. In : C.E. Lee \& P. W. Lynch (eds). Trochus: status, hatchery practice and nutrition. ACIAR Proceeding $79: 33$ - 37.

Dwiono, S.A.P. and D.E.D. Setyono 1999. Influence of density on the growth rate of greensnail, Turbo marmoratus L. (Mollusca; Gastropoda), in cages. Phuket Mar. Bio. Cen. Spec. Publ. 19 : 213 - 217.

Dwiono, S.A.P. and D.E.D. Setyono 2003. Stocking density and growth of juvenile green snail (Turbo marmoratus) cultured in cages placed on intertidal area. . Paper presented at Annual Scientific Meeting 2003, Indonesian Association of Oceanologist. Jakarta, 10-11 December 2003.

Kubo, H. 1991. Topshell (Trochus niloticus), green snail (Turbo marmoratus) and turban snail (Turbo argyrostomus). In : S. Shokita, K. Kakazu, A. Tomori
\& T. Toma (eds). Aquaculture in tropical areas. Midori Shobo, Tokyo: 276 - 282.

Setyono, D.E.D. and S.A.P. Dwiono 1998. Studi pembesaran anakan batulaga (Turbo marmoratus Linnaeus, 1758) dengan pakan alami dan Navicula spp. yang ditumbuhkan pada substrat karang mati dan cangkang kerang. Perairan Maluku dan Sekitarnya $12: 1$ - 9

Setyono, D.E.D. and S.A.P. Dwiono 2003. Feeding rate and growth of juvenile green snail (Turbo marmoratus) fed by macro algae. Paper presented at Annual Scientific Meeting 2003, Indonesian Association of Oceanologist. Jakarta, 10-11 December 2003.

Yamaguchi, M. 1993. Green snail. In A. Wright \& L. Hill (eds). Nearshore marine resources of the South Pacific. International Center for Ocean Development, Canada : 497-511. 